\title{
Aktivitas Antibakteri Yogurt Susu Phaseolus vulgaris L. dan Phaseolus radiatus L. dengan Penambahan Madu terhadap E. coli, S. aureus, dan Extended Spectrum 6-Lactamase (ESBL)
}

\section{Antibacterial Activities of Phaseolus Vulgaris L. and Phaseolus Radiatus L. Yogurt Milk with Honey Against E. coli, S. aureus, and Extended Spectrum $\beta$-Lactamase (ESBL)}

\author{
lif Hanifa Nurrosyidah ${ }^{10}$, Amriyati Fitriana Kusumastuti ${ }^{2}$, Dimas Candra Rahmadani ${ }^{1}$, Erdina Kusumastuti ${ }^{1}$ \\ ${ }^{1}$ Program Studi D3 Farmasi, STIKES Rumah Sakit Anwar Medika, Jl. Raya By Pass Krian KM 33, Sidoarjo Jawa Timur. \\ ${ }^{2}$ Program Studi S1 Farmasi, STIKES Rumah Sakit Anwar Medika, Jl. Raya By Pass Krian KM 33, Sidoarjo Jawa Timur.
}

\begin{abstract}
Abstrak: Infeksi merupakan penyakit yang menjadi masalah kesehatan di seluruh dunia termasuk Indonesia. Saat ini probiotik banyak dikembangkan untuk mengatasi atau mencegah berbagai penyakit, salah satunya yaitu infeksi. Penelitian uji aktivitas antibakteri pada yogurt susu kacang merah dan kacang hijau dengan madu dilakukan terhadap bakteri Escherichia coli, Staphylococcus aureus, Extended spectrum $\beta$ lactamase (ESBL)dengan metode cakram. Berdasarkan hasil penelitian yang telah dilakukan diperoleh aktivitas antibakteri dari yogurt tersebut adalah sedang sampai kuat.

Kata Kunci: bakteri, infeksi, yogurt.

Abstract: Infectious is a disease that is a health problem throughout the world, including Indonesia. Bacteria are the main cause of infectious diseases. Currently, many probiotics are developed to overcome or prevent various diseases, one of which is infection. This research was conducted to test the antibacterial activity of red bean and green bean milk yogurt with honey against Escherichia coli, Staphylococcus aureus, Extended spectrum $\beta$-lactamase (ESBLusing paper disk method. Based on this result the inhibition of this antibacterial activity categorized as moderate to strong.

Keywords: bacteria, infection, yogurt.
\end{abstract}

\section{PENDAHULUAN}

Saat ini probiotik banyak dikembangkan untuk mengatasi atau mencegah berbagai penyakit, salah satunya yaitu infeksi. Probiotik adalah istilah yang digunakan pada mikroorganisme hidup yang dapat memberikan efek baik atau kesehatan pada organisme lain/inangnya. Probiotik secara alami dapat diperoleh dari buah dan sayur seperti buah markisa merah (Nurrosyidah et al., 2020). Yogurt adalah susu yang dibuat melalui fermentasi bakteri yang bersifat asam. Bila dikonsumsi secara rutin bahkan mampu menghambat kadar kolesterol dalam darah karena yogurt mengandung bakteri lactobacillus (Wahyudi, 2006).

Madu dihubungkan dengan aktivitas antibakteri pada yogurt, karena madu akan bekerja untuk menarik air keluar dari zat asing itu sehingga bakteri menjadi tidak berdaya, madu juga tidak mengandung cukup air sehingga bakteri tidak bisa hidup. Madu mengandung berbagai jenis gula, diantaranya fruktosa $41 \%$, glukosa $35 \%$ dan sukrosa $1,9 \%$. Yogurt biasanya terasa asam, oleh karena itu

- email korespondensi: iifhanifanurrosyidah@gmail.com 
penambahan madu sebagai pemanis alami adalah solusi yang dapat dicoba untuk menambahkan rasa manis pada yogurt (Nofrianti dkk,2013).

\section{METODE PENELITIAN}

\section{Bentuk Penelitian}

Jenis penelitian yang digunakan adalah penelitian eksperimental, dengan tujuan utama menguji coba suatu objek penelitian, kemudian dilihat zona hambat yogurt susu kacang merah dan susu kacang hijau dengan madu terhadap pertumbuhan bakteri Escherichi coli, Staphylococcus aureus, Extended spectrum 8 lactamase dan Methicilin resisant saphylococcus aureus. Dimana penelitian ini menggunakan metode sumuran.

Metode sumuran memiliki kelebihan yaitu lebih mudah mengukur luas zona hambat yang terbentuk karena isolat beraktivitas tidak hanya di permukaan atas nutrien agar tetapi juga sampai ke bawah (Haryati dkk. 2017) sedangkan kekurangannya yaitu pada metode ini media sangat rentan terkontaminasi pada saat pembuatan lubang dan memasukan sampel karena sering membuka cawan (Retnaningsih dkk. 2019).

\section{Alat}

Alat yang digunakan dalam penelitian kali ini adalah gelas ukur $10 \mathrm{~mL}, 100 \mathrm{~mL}, 500 \mathrm{~mL}$ (Merk ${ }^{\circ}$ ), erlenmeyer $250 \mathrm{ml}, 500 \mathrm{~mL}$ (Merk ${ }^{\circ}$ ), tabung reaksi (Duran ${ }^{\circ}$ ), rak tabung reaksi, pipet tetes, penangas air, kaca arloji, timbangan analitik (Shimadzu ${ }^{\circledR}$ ), stirer, cawan petri, jarum ose, cotton bud, inkubator (Memmert ${ }^{\circledR}$ ), autoklaf, mikropipet, aluminium foil, dan mistar berskala.

\section{Bahan}

Bahan yang digunakan dalam penelitian kali ini adalah yogurt susu kacang merah dan susu kacang hijau, aquades steril, antibiotik ciprofloksasin, antibiotik ampisilin, antibiotik meropenem. Nutrient Agar (NA), Nutrient Broth (NB), kertas label, kertas wripe, Bakteri Escherichia coli, Staphylococcus aureus serta Extended Spectrum 8 Lactamase (ESBL) yang diperoleh dari Laboratorium Mikrobiologi Stikes RS Anwar Medika Sidoarjo.

\section{Perhitungan Replikasi}

Penentuan jumlah replikasi yaitu melalui perhitungan menggunakan rumus Federer.

Rumus Federer:

$$
\text { Rumus }=(k-1) \cdot(n-1) \geq 15
$$

(Firdaus, 2014)

\section{Keterangan :}

$\mathrm{k}=$ jumlah kelompok perlakuan

$\mathrm{n}=$ jumlah sampel dalam tiap kelompok

Dan perhitungannya adalah sebagai berikut :

Rumus $=(k-1) \cdot(n-1) \geq 15$

$$
\begin{aligned}
& =(k-1) \cdot(7-1) \geq 15 \\
& =(k-1) \cdot 6 \geq 15 \\
& =6 k-6 \geq 15 \\
& =6 k \geq 21 \\
& =k \geq 4
\end{aligned}
$$

Hasil perhitungan menunjukkan bahwa replikasi berjumlah 4 kali replikasi. Namun untuk mengantisipasi kegagalan percobaan replikasi maka dalam penelitian ini ditetapkan penambahan jumlah replikasi menjadi 5 kali.

\section{Pembuatan Kontrol Negatif dan Positif}

Kontrol negatif yang digunakan dalam penelitihan kali ini adalah aquadest steril dan kontrol positif dibuat dari sediaan obat ciproflosaksin, ampicillin dan meropenem.

\section{Pembuatan Media}

\section{Pembuatan Media Agar}

Nutrient Agar (NA) ditimbang sebanyak 2 gram dilarutkan dalam $100 \mathrm{ml}$ aquades menggunakan erlenmeyer. Setelah itu dihomogenkan dengan stirer diatas penangas air sampai mendidih. Sebanyak $12 \mathrm{ml}$ dituangkan masing-masing pada 5 cawan petri. Media tersebut disterilkan dalam autoklaf pada suhu $121^{\circ} \mathrm{C}$ selama 15 menit, kemudian dibiarkan pada suhu ruangan selama sampai media memadat.

\section{Pembuatan Media Peremajaan Bakteri}

Media peremajaan bakteri dibuat dengan cara ditimbang 0,08 gram Nutrient Broth (NB), lalu dilarutkan dalam $10 \mathrm{ml}$ aquades menggunakan erlenmeyer. Setelah itu, disterilkan dalam autoklaf pada suhu $121^{\circ} \mathrm{C}$ selama 15 menit, kemudian didinginkan di suhu ruang. 


\section{Peremajaan Bakteri}

Bakteri uji yang telah diinokulasi diambil dengan kawat ose steril lalu digoreskan kedalam tabung yang berisi $10 \mathrm{ml}$ Nutrient Broth (NB) kemudian beri sumbat dan wrap dengan plastic wrap lalu inokulasikan dengan incubator selama 24 jam.

\section{Pembuatan Suspensi Bakteri Uji}

Komposisi larutan Mc Farland 0,5 adalah $\mathrm{H}_{2} \mathrm{SO}_{4} 1 \% 9,95 \mathrm{~mL}, \mathrm{BaCl}_{2} 1 \%$ 0,05 mL. Pembuatan larutan $\mathrm{H}_{2} \mathrm{SO}_{4} 1 \%$ dengan cara mengambil $1 \mathrm{~mL}$ larutan $\mathrm{H}_{2} \mathrm{SO}_{4}$ di larutkan dalam $10 \mathrm{~mL}$ aquadest dan untuk membuat larutan $\mathrm{BaCl}_{2} 1 \%$ di lakukan dengan cara menimbang 0,1 $\mathrm{BaCl}_{2}$ dan di larutkan dalam 10 $\mathrm{mL}$ aquadest. Pembuatan larutan Mc Farland di lakukan dengan cara mengambil 9,95 $\mathrm{mL} \mathrm{H}_{2} \mathrm{SO}_{4}$ di campur dengan larutan $\mathrm{BaCl}_{2}$ 0,05 mL.

\section{Uji Aktivitas Antibakteri}

Untuk uji metode sumuran dilakukan dengan pour plate dilakukan dengan mengambil 8 $\mathrm{mL}$ media nutrient agar dan di tuangkan ke dalam cawan petri steril sebagai base layer di tunggu sampai padat. Kemudian tuangkan $10 \mathrm{~mL}$ media nutrient agar ditambah mikrorganisme uji ke dalam cawan petri tersebut. Setelah itu media di ratakan dengan menggoyangkan cawan petri dan di inkubasi pada suhu $20^{\circ} \mathrm{C}$ selama 24 jam. Dengan total keseluruhan membutuhkan 16 cawan petri. Selanjutnya media yang sudah terdapat bakteri tersebut dilubangi dengan lubang pipet atas masingmasing 5 kali replikasi sampel, satu kontrol positif dan satu untuk kontrol negatif dalam satu cawan petri. Kemudian masing-masing sampel formula dimasukkan dalam 5 lubang yang sudah dibuat dan antibotik amicillin, ciprofloxacin, dan meropenem sebagai kontrol positif. Ditutup rapat dan berikan plastik wrap, inkubasi selama 24 jam untuk melihat hasilnya. Jika dalam media tersebut terbentuk zona hambat maka yogurt susu kacang merah dan susu kacang hijau memiliki aktivitas antibakteri tersebut.

\section{HASIL DAN PEMBAHASAN}

Pada tabel 1. dapat dilihat penelitian uji aktivitas antibakteri yogurt susu kacang hijau dan yogurt susu kacang merah terhadap bakteri Extended spectrum b lactamase. Namun zona hambat yang dibentuk oleh yogurt susu kacang hijau dan yogurt susu kacang merah tidak melebihi zona hambat yang dibentuk oleh kontrol positif (meropenem). Dapat dilihat dari hasil yang didapat, semakin tinggi konsentrasi yang digunakan maka semakin besar pula zona hambat yang dihasilkan.

Tabel 1. Hasil uji aktivitas antibakteri ESBL yogurt susu kacang hijau dan susu kacang merah

\begin{tabular}{cccc}
\multirow{2}{*}{ Perlakuan } & \multicolumn{3}{c}{ Zona hambat $(\mathbf{m m})$} \\
\cline { 2 - 4 } & F1 & F2 & F3 \\
\hline Kontrol (-) & - & - & - \\
Kontrol (+) & 23 & 24 & 25 \\
R 1 & 13 & 12 & 12 \\
R 2 & 13 & 13 & 12 \\
R 3 & 12 & 14 & 14 \\
R 4 & 10 & 10 & 14 \\
R 5 & 11 & 12 & 12 \\
\hline Rata-rata & 11 & 12 & 12 \\
\hline
\end{tabular}

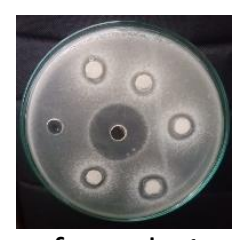

formula 1

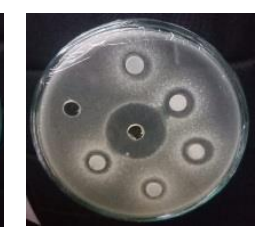

formula 2 formula 3

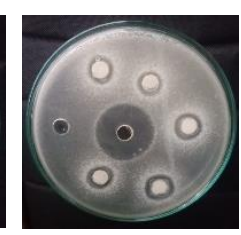

Gambar 1. Zona Hambat terhadap bakteri Extended spectrum $B$ lactamse (ESBL)

Dari gambar dan tabel di atas dijelaskan bahwa formula 1 dengan rata-rata $11 \mathrm{~mm}$ membuktikan bahwa formula 1 mampu menghambat pertumbuhan bakteri Extended spectrum $B$ lactamse dengan kategori kuat (10-20 $\mathrm{mm}$ ). Kemudian formula 2 dengan rata-rata $12 \mathrm{~mm}$ membuktikan bahwa formula 2 mampu menghambat pertumbuhan bakteri Extended spectrum $B$ lactamse dengan kategori kuat (10-20 $\mathrm{mm}$ ). Kemudian formula 3 dengan rata-rata $12 \mathrm{~mm}$ membuktikan bahwa formula 3 mampu menghambat pertumbuhan bakteri Extended spectrum B lactamse dengan kategori kuat (10-20 $\mathrm{mm})$.

Pada tabel 2. dapat dilihat hasil uji aktivitas antibakteri yogurt susu kacang hijau dan yogurt susu kacang merah terhadap bakteri Esherechia coli. Namun zona hambat yang dibentuk oleh yogurt susu kacang hijau dan yogurt susu kacang merah tidak melebihi zona hambat yang dibentuk oleh kontrol positif (ciprofloxacin). Dapat dilihat dari hasil yang 
didapat, semakin tinggi konsentrasi yang digunakan maka semakin besar pula zona hambat yang dihasilkan.

Tabel 2. Hasil uji aktivitas antibakteri Esherichia coli yogurt susu kacang hijau dan susu kacang merah

\begin{tabular}{cccccc}
\hline \multirow{2}{*}{ Perlakuan } & \multicolumn{5}{c}{ Zona hambat (mm) } \\
\cline { 2 - 6 } & F1 & F2 & F3 & F4 & F5 \\
\hline Kontrol (-) & - & - & - & & \\
Kontrol (+) & 22 & 18 & 17 & 18 & 20 \\
R 1 & 12 & 13 & 12 & 11 & 11 \\
R 2 & 11 & 11 & 11 & 14 & 11 \\
R 3 & 13 & 13 & 11 & 15 & 11 \\
R 4 & 11 & 11 & 9 & 9 & 15 \\
R 5 & 14 & 11 & 17 & 11 & 13 \\
\hline Rata-rata & 12 & 15 & 10 & 12 & 12 \\
\hline
\end{tabular}

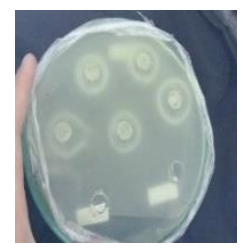

formula 1

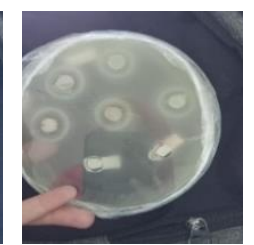

formula 2

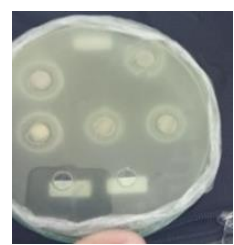

formula 3

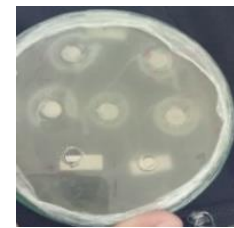

formula 4

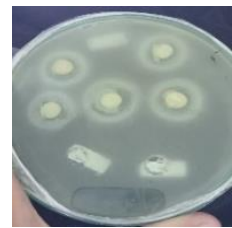

formula 5
Gambar 2. Zona Hambat terhadap bakteri Esherichia coli

Dari gambar dan tabel di atas dijelaskan bahwa formula 1 dengan rata-rata $12 \mathrm{~mm}$ membuktikan bahwa formula 1 mampu menghambat pertumbuhan bakteri Escherichia coli dengan kategori kuat (10-20 mm). Kemudian formula 2 dengan rata-rata $15 \mathrm{~mm}$ membuktikan bahwa formula 2 mampu menghambat pertumbuhan bakteri Escherichia coli dengan kategori kuat (10-20 mm). Kemudian formula 3 dengan rata-rata $10 \mathrm{~mm}$ membuktikan bahwa formula 3 mampu menghambat pertumbuhan bakteri Escherichia coli dengan kategori sedang (5-10 $\mathrm{mm})$. Kemudian formula 4 dan 5 dengan rata-rata 12 mm membuktikan bahwa formula 4 dan 5 mampu menghambat pertumbuhan bakteri Escherichia coli dengan kategori kuat (10-20 mm).

Pada tabel 3. dapat dilihat penelitian uji aktivitas antibakteri yogurt susu kacang hijau dan yogurt susu kacang merah terhadap bakteri
Staphylococcus aureus. Namun zona hambat yang dibentuk oleh yogurt susu kacang hijau dan yogurt susu kacang merah tidak melebihi zona hambat yang dibentuk oleh kontrol positif (ampicillin). Dapat dilihat dari hasil yang didapat, semakin tinggi konsentrasi yang digunakan maka semakin besar pula zona hambat yang dihasilkan.

Tabel 3. Hasil uji aktivitas antibakteri Staphyococcus aureus yogurt susu kacang hijau dan susu kacang merah

\begin{tabular}{cccccc}
\multirow{2}{*}{ Perlakuan } & \multicolumn{5}{c}{ Zona hambat (mm) } \\
\cline { 2 - 6 } & F1 & F2 & F3 & F4 & F5 \\
\hline Kontrol (-) & - & - & - & & \\
Kontrol (+) & 30 & 25 & 20 & 30 & 25 \\
R 1 & 12 & 10 & 10 & 6 & 9 \\
R 2 & 13 & 11 & 9 & 7 & 7 \\
R 3 & 10 & 12 & 9 & 17 & 8 \\
R 4 & 13 & 19 & 8 & 16 & 10 \\
R 5 & 9 & 18 & 11 & 17 & 10 \\
\hline Rata-rata & 14,5 & 15,8 & 11,7 & 15,5 & 11,5 \\
\hline
\end{tabular}

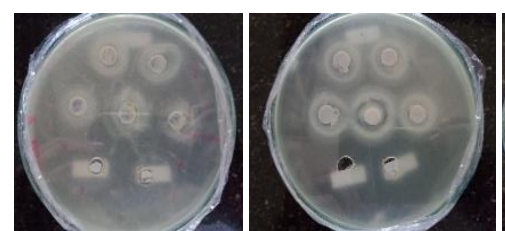

formula 1

formula 2

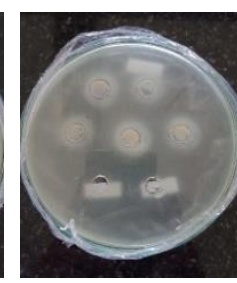

formula 5

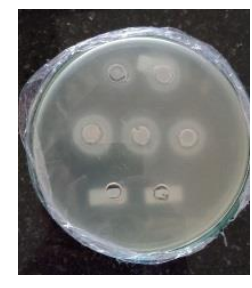

formula 4

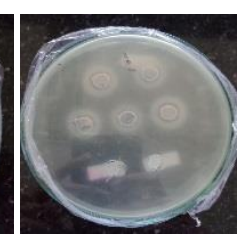

formula 3

\section{Gambar 3. Zona Hambat terhadap bakteri Staphyococcus aureus}

Dari gambar dan tabel di atas dijelaskan bahwa formula 1 dengan rata-rata $14,5 \mathrm{~mm}$ membuktikan bahwa formula 1 mampu menghambat pertumbuhan bakteri Staphyococcus aureus dengan kategori kuat (10-20 mm). Kemudian formula 2 dengan rata-rata $15,8 \mathrm{~mm}$ membuktikan bahwa formula 2 mampu menghambat pertumbuhan bakteri Staphyococcus aureus dengan kategori kuat (10-20 mm). Kemudian formula 3 dengan rata-rata $11,7 \mathrm{~mm}$ membuktikan bahwa formula 3 mampu menghambat pertumbuhan bakteri Staphyococcus aureus dengan kategori kuat 
(10-20 mm). Kemudian formula 4 dengan rata-rata 15,5 mm membuktikan bahwa formula 4 mampu menghambat pertumbuhan bakteri Staphyococcus aureus dengan kategori kuat (10-20 mm). Kemudian formula 5 dengan rata-rata $11,5 \mathrm{~mm}$ membuktikan bahwa formula 5 mampu menghambat pertumbuhan bakteri Staphyococcus aureus dengan kategori kuat (10-20 mm).

\section{SIMPULAN}

Yogurt susu kacang hijau (Phaseolus

Radiatus L.) dan yogurt susu kacang merah (Phaseolus Vulgaris L.) mampu meghambat pertumbuhan bakteri Escherchia coli, Staphyococcus aureus, Extended spectrum $B$ lactamase dengan kategori sedang sampai kuat.

\section{DAFTAR PUSTAKA}

Finarsih, F. (2014). Uji Kualitas Yogurt Susu Sapi dengan Penambahan Madu dan Lactobacilus bulgaricus pada Konsentrasi yang Berbeda.
Firdaus,T. (2014). Evektivitas Ekstrak Bawang Dayak (Eleutherine Palmifolia) Dalam Menghambat Pertumbuhan Bakteri Staphylococcus Aureus. Skripsi, 14.

Haryati, dkk. (2017). Perbandingan Efek Ekstrak Buah Alpukat (Persea americana Mill) Terhadap Pertumbuhan Bakteri Pseudomonas Aeruginosadengan Metode Disk dan Sumuran. Prosiding Seminar Nasional Publikasi Hasil-Hasil Penelitian dan Pengabdian Masyarakat, 348.

Nurrosyidah, I. H., \& Mertaniasih, N. M. (2020). Potential Probiotic from Indigenous Indonesian Red Passion Fruit (Passiflora edulis Sims). Systematic Reviews in Pharmacy, 11(8), 123-130.

Retnaningsih, dkk. (2019). Uji Daya Hambat Ekstrak Etanol Biji Pepaya Terhadap BakteriEscherichia colidan Shigella dysentriae dengan Metode Difusi Sumuran.Jurnal Analisis Farmasi, 122 - 129. 